\title{
6 Funny Matter
}

\subsection{Humorous Humanity}

When understood merely as an aesthetic modality, improvisation does not need to be funny. However, I am concerned with the specific cultural configuration of US improv, which may be framed as an "artform that stands on its own, with its own discipline and aesthetics," on the one hand, but almost always uses improv and comedy as "synonyms" on the other (Close et al. 14). Including humor in the list of investigative frames of this project alongside intuition and play, I take my cue from the highly influential improv manual Truth in Comedy, in which authors Del Close, Charna Halpern, and Kim Johnson "politely tip [their] hats in acknowledgment of the more serious uses of improvisation and saunter off in the direction of chuckles, chortles and guffaws" (14-15). There is ample reason for that; when we look at the curriculum vitae of improvisers who succeed in show business, we see that they have almost exclusively made it in comedy, whether hosting, writing for or side-kicking in late shows, starring in comedy movies, or performing on SNL. So there is no reason to detach improv from "the funny," which constitutes a central momentum in its discourse and practice. Improv discourse holds various positions on where "the funny" lives and how to get there. My aim is not to categorize or judge it, but to consider how humor is theorized and what that theorization - including the "observations" on which it is based - tells us about the role and function of humor and laughter for the white modern subject in general, and for improv comedy's anti-Blackness in particular.

Not unlike improvisation studies, contemporary humor studies is a rich academic field. And like improvisation studies, it is an interdisciplinary one: anthropology, social sciences, psychology, philosophy, linguistics, cognitive neuroscience, mathematics, and computational linguistics in artificial intelligence are only some of the fields that have discovered humor as an object of interest. The International Society for Humor Studies (ISHS) is comprised of scholars from such diverse fields as "the Arts and Humanities, Biological and Social Sciences, and Education" and "also includes professionals in the fields of counseling, management, nursing, journalism, and theater." The society studies "humor's many facets, including its role in business, entertainment, and health care as well as how humor varies according to culture, age, gender, purpose, and context" ("International Society"). Yet even with humor theory as an umbrella term for these disciplines, their definitions, terminologies, and methodologies are too diverse to constitute a solid ground for interdisciplinary endeavors. Some talk about the communicative function of laughter (signaling play or lack 
of aggression), others about its social effect (degrading those who do not represent the default defined by the laughers). Neuroscientists analyze the biochemistry of laughing (in the release of endorphins) while others discuss how objects become or why they are funny. In his dismissal of Hobbesian humor theory, Noël Carroll argues that his approach is "framed in terms of laughter [which undoubtedly] enhances the intuitive plausibility [because] laughter often accompanies triumph," which makes him question whether laughter is "the proper object for a theory of humor" (16). While I appreciate Carroll's differentiation of laughter and humor and his emphasis on humor as a primarily social process, it must be recognized that laughter returns into the concept of humor, for example by way of its communicative function. This social dimension presupposes a sociality in which humor can be performed, and whether scholars are analyzing humor or laughter, the question of being human returns here as a central aspect in the discourse. If neuroscience seeks to discover the biochemical processes behind the elicitation of laughter, this interest is cued by earlier theorists who consider humor, laughter, and the comic not only worthy of study, but central to the study of Humanity as such. The reverse is also true: when mainstream scholarship asks what characterizes Humans (usually in distinction from animals), humor often features as a quality that only Humans possess. Most humor theorists state that "even if it is not the case that humor is a uniquely human phenomenon, it seems to be a nearly universal element of human societies," which is why "it has been a perennial topic for speculation, especially on the part of thinkers ambitious enough to attempt to comment on every facet of human life" (Carroll 6). The result is a myriad of variations on these questions: what are humor's social and individual functions? What makes a given object, text, or situation funny? Are humor or laughter anthropological constants? Is there an anthropological formula that explains how humor works? Is humor linked to what we know as evolution?

This project is not designed to redefine humor studies in general, nor do I claim that these questions are inherently wrong. My point is that in their fundamentally and radically Humanist approaches, humor theorists have not and could never be interested in a critique of that very Humanism. Instead, the Human has been romanticized as a stable and universal referent through which the field has attained and maintains its legitimacy. A fundamental critique - that is, the recognition of Humanity's cultural specificity as opposed to its assumed universality - would challenge not only the legitimacy of the object of study, but the axiomatic setup through which that object attains significance in the first place. The agnotological defense mechanisms are all in order; in most writings that consider race as a factor at all, it is treated as an example of either ethnic (for survival) or derogatory (for superiority) humor, based 
on degrading stereotypes. We must therefore reassess the argumentative tradition of the rhetorical repertoire mobilized in humor studies. I do so by close reading some central tenets of the humor studies canon as well as the terms of their elaboration. The latter have not only been influential in the making of the discipline as a whole; they also teach us how we know, live, and practice humor as subjects of white supremacist modernity.

Classical humor theory is traditionally differentiated into three categories: superiority theories, release/relief theories, and incongruity theories. On closer inspection, these strands are not separate: there is superiority in relieving laughter and incongruity in the laughter of superiority, while release/relief theories work from both of these. I first draw on Freud's release/relief approach as a central reference, and then consider Henri Bergson's superiority theory, which Freud received favorably. A critical close reading of Bergson's overtly racial argument crystallizes many of strands in this project so far. Finally, I consider the development of so-called "incongruity theories" by tracing the history of Bergson's theoretical trajectory. Early incongruity theories provide the ground for the many different and specific approaches that contemporary humor studies build on today. Here too, by way of their historical trajectory, even the most analytic approaches are always bound to anti-Black dehumanization as the solipsist vector that reasserts the white human subject of modernity. I argue that the term "incongruity" already veils the racially abjective origins of Blackness-as-a-joke in the same way that "musical collaboration" obliterates Blackness-as-jazz.

\subsection{Humor and the libidinal economy of anti-Black abjection}

\section{The joke and libidinal economy}

Freud's humor theory is grounded in and articulated through libidinal economy. In discussing jokes or joke-work, Freud also talks about the mechanics of the unconscious, which motivate joking. Thus, with Freud, one cannot conceive of a joke as purely aesthetic. In The Joke and Its Relation to the Unconscious, Freud writes:

[W]hat we described as joke-techniques - and in a certain sense we must continue to give them this name - are rather the sources from which the joke obtains the pleasure; and we do not feel disconcerted that other procedures should draw from the same sources to the same end. (125) 
Discussing humor via Freud always points beyond "the funny" itself, locating it along with laughter and humor in a larger theoretical framework. ${ }^{1}$ Freud considers joking as a way to circumvent inner or outer obstacles, the latter standing in the way of the fulfillment of the (sex) drive. Navigating around such obstacles provides jouissance qua avoidance or the prevention of what he calls (with Theodor Lipps) the "psychical damming-up" of libidinal energy. Through humor, and especially in the fictionality of the theater stage, such intentions, such tendencies, may find satisfaction. The same is true for internal obstacles like norms and values. In both cases, Freud argues, the gain in pleasure corresponds to the amount of "psychical expenditure" saved rather than spent on the creation or maintenance of such obstacles. He discusses saving psychical expenditure through various technical aspects of jokes, which first set up and then relieve psychical damming-up (114). In view of their similar technical modi operandi, Freud asserts a likeness between joke-work and dream-work. ${ }^{2}$ He assumes that the function of a dream is analogous to the creation of a joke: "A preconscious thought is given over for a moment to unconscious revision, and the result promptly grasped by conscious perception" (161). This relates humor theory to my discussion of intuition and play. Importantly, however, jokes function like but are not the same as dreams for Freud: while dreaming is non-social, joking requires sociality, both in its performative theatricality and in the sense that it engenders sociality at large. The communicational and performative features of joke-work distinguish it from dream-work, yet both are psychic processes working toward homeostasis in collective and individual libidinal economy: "The dream predominantly serves to spare ourselves unpleasure, the joke to gain pleasure; but in these two aims, all our psychical activities meet” (Joke 173).

Given the role of the unconscious and the desires that libidinal economy creates - specifically the sociogenic libidinal economy of Western modernity, invis-

1 Why engage with Freud's allegedly outdated and overused theory of humor, now mostly treated with historic interest? Whether Freud can provide insight into a higher truth beyond the cultural episteme in which he and I are theorizing is not a question I seek to ask or answer. Nonetheless, I believe it is worthwhile engaging with him without falling for his universalist assumptions, because I find value in the larger theoretical framework of libidinal economy.

2 Freud writes further: "The interesting processes of condensation with substitute-formation which we have recognized to be the core of the joke-technique in verbal jokes pointed us towards the formation of dreams, for the same psychical processes have been discovered in the mechanism at work here. But that is the very same direction to which the techniques of intellectual jokes also point - displacement, faulty thinking, absurdity, indirect representation, representation by the opposite - and all of these without exception recur in the dream-work [...] Such a farreaching correspondence as the one between the devices of the joke-work and those of the dream-work will hardly be incidental” (75). 
ible to its subjects - we white subjects can never be sure what exactly we are laughing about, or why we are laughing so hard at something. Freud writes:

[A] good joke makes a general impression of pleasing [Wohlgefallen], so to speak, without being capable of distinguishing directly what part of the pleasure [Lust] comes from the form of the joke and what from its admirable thought-content [Gedankeninhalt]. We are constantly deluding ourselves on this division, now overestimating the quality of the witticism on account of our admiration of the thought it contains, now contrariwise, the value of the joke on account of the amusement we have from how it is clad in a joke. We do not know what is amusing us or what we are laughing at. (Joke 126)

The jokers, as much as their audience, are only partly aware of (or morally responsible for) the "funny idea" that crossed their mind, because the origin of the joke is not conscious but intuitive. This is especially significant in the sphere of white spontaneous play with Black-racialized scene partners as transitional objects in the scene:

It is true, we say, one "makes" a joke, but we sense that when we do so, we are behaving differently from when we make a judgment or an objection. A joke has quite outstandingly the character of a "bright idea," occurring to us involuntarily [...] One senses rather something indefinable, which I would best compare with an absence, a sudden letting go of intellectual tension, and then all at once, the joke is there. (Joke 162)

When the subject makes a joke, as in intuitive action, "revelation burst[s] forth," as Kristeva describes the moment of abjection (8). Taking our cue from her statement that "[l]aughing is a way of placing or displacing abjection" (8) we can figure that, though not the same, making a joke and acting on abjective intuition give us white subjects similar sensations. And both lead us to believe that whatever content emerges has somehow mystically occurred to us. A quick look at Freud's original German text is insightful, as it mobilizes a transumed variant of the Reason/Flesh dichotomy, while the English translation mobilizes a Light/Dark dichotomy - both solidly grounded in the modern matrix as analyzed by Wynter. Freud uses the German Einfall to modify "idea" in the quotation above, which literally translates to "something that fell into" something else, a Human mind specifically. That is, an idea fell from somewhere into the subject without the latter contributing anything. It fell from above, presumably from the sphere of Gods and Reason, an ancient cosmic truth. Translating Einfall into English as "bright” instead mobilizes tropes of knowledge and light. The assumption is that the unconscious speaks through the improviser, providing "bright" ideas in the same way that God or any spirit of perfect and transcendental knowledge uses the Human subject to speak. The idea of the humorous im- 
proviser as a medium or channeler crops up again, echoing also with the vitalist notion that an external force brings spiritual and actual life to matter.

\section{Abjective tendencies in joke-work}

In terms of content, Freud introduces two extreme poles: the "innocuous" and the "tendentious" joke. The innocuous joke is an "end in itself," a blaguepour-blague, while the latter serves a "particular purpose," thus becoming "tendentious" (85). Unlike the innocuous joke, which is "without content," the tendentious one is "profound" (89). Freud theorizes the innocuous joke in line with Kantian aesthetics as "interesselos" (disinterested), imagining a condition in which "we demand nothing of things, nor wish to do anything with them" (90). The innocuous joke is one of fantasized and fetishized High Reason. (This Kantian vein is obviously racialized, as is Kant's theorizing on the modern Human.) The tendentious joke appears more instructive. With regard to its libidinal effect on those making or receiving it, Freud presents the tendentious joke as vastly superior to the innocuous one:

An un-tendentious joke scarcely ever achieves those sudden outbursts of laughter that make tendentious jokes so irresistible. As the technique can be the same in both, we may find the suspicion stirring that a tendentious joke has sources of pleasure at its disposal - by virtue of its tendency - to which innocuous jokes have no access. (91-92)

With Freud, we can argue that the tendentious joke offers a fulfilling humorous experience not despite but because we white modern subjects do not consciously know what exactly we laugh at:

Tendentious jokes are able to release [entbinden] pleasure even from those sources that are subject to repression [...] Out of all the developmental stages of a joke, the most important characteristic of joke-work - that it sets pleasure free by removing inhibitions - is most clearly shown in the tendentious joke. It reinforces tendencies it serves by bringing them assistance from impulses kept suppressed, or it puts itself generally at the disposal of suppressed tendencies. (129)

The power of what happens in the depths of the body is precisely what makes tendentious jokes (or the tendentious quality of all joke-work) "irresistible"; unlike the innocuous joke, the tendentious joke has the entire body-brain apparatus working for it. The "pleasure aimed for is not only the pleasure generated by the joke; it is incomparably greater" (131). Freud further distinguishes between two kinds of tendentious joke: the "hostile joke (used for aggression, satire, de- 
fense)" and the “obscene joke (used to strip someone naked) [Entblößung]” (92). The hostile joke describes an act of aggression relocated to the realm of the imaginative, that is, the vicarious overcoming of an outer obstacle. The hostile tendentious joke invites its partakers - the performer, the audience - to imagine the destruction of whomever the joke is directed against. Freud thus considers it "well suited to attacking the great, the dignified and the mighty - powers protected from direct disparagement by internal inhibitions or external circumstances" (100).

Superficially, this distinction does not appear to communicate at all with the rest of this project. Modern Blackness is not great, dignified, or mighty, but open for gratuitous and unsanctioned violation. Structurally speaking, no inhibitions or circumstances protect Blackness from attack, and so the humor mode is unnecessary because no obstacle needs to be overcome. In this strict sense, the imaginative, fictional, symbolic reenactment of lynching on the improvised scene is not the overcoming of an obstacle, but merely draws on a cultural repertoire that ensures that Blackness will never signify or represent "hindrance." To make sense of Freudian humor theory in view of the humorous dehumanization of Blackness, the hostile tendentious joke must be understood as inclusive of gratuitously violent destruction. This particular jouissance comes from the omnipotent control over an externality, and relates to my earlier discussion of play as "transitional Blackness." Acts of humorous anti-Black abjection provide jouissance in themselves without needing to be jokes in the strict meaning of the word. The somatic experience of such anti-Black abjection is simply the easiest thing to do for whites. It comes naturally to the modern subject and provides a way to release any tension a nervous improviser might feel on stage. In view of anti-Blackness, then, Freud's notion of an external obstacle to be overcome only translates if we read the mere presence of a racialized, thingified body as an obstacle to (but also as available matter for) Human play as such. In keeping with Winnicott's theory, transitional Blackness on the humor stage functions as a killable vehicle that never goes away and can be drawn upon for continual destruction. The tendentious jouissance set free by anti-Black abjection is so powerful and joyful for white jokers and their audiences that it can override the comedian's (assumedly primary) task of crafting jokes.

Whereas the hostile joke is driven by phobia, the obscene joke is driven by desire. Freud analyzes bawdry, which he defines in commonplace terms as the "deliberate emphasizing [of] sexual facts and relations by talking about them [...] directed at a particular person by whom the speaker is sexually aroused" (92). Bawdry talk is an attempt to seduce or to shame. Freud elaborates at length in gender essentialist terms, but one brief section is particularly significant because it refers to his understanding that "the content of bawdry includes [...] 
what the two [sic] sexes have in common to which the feeling of shame extends, that is excremental subject-matter in all its range" (93). Freud suggests that at the infant stage, "what is sexual and what is excremental are distinguished badly or not at all” (93). Excremental matter, Kristeva's horror, falls right in the field of abjection: the Fallen Flesh, the existentially abjected not-me of the subject. Blackness signifies physical matter as well as white sexual desire. Like the hostile joke, which can be understood to serve aeffects of destruction, as an example of obscene joking, bawdry talk is a means of attaining certain pleasures in a way that reality would not normally permit: "Bawdry is like an act of unclothing the person [...] at whom it is directed. By voicing the obscene words, it forces the person attacked to imagine the particular part of the body or the act involved and shows them that the aggressor himself is imagining it” (93). In the presence of Blackness, however, the hostile and the obscene joke cannot be distinguished from another because fear and desire aeffect the modern white subject simultaneously. The white subject derives libidinal pleasure precisely qua destruction by calling out Blackness. Recall the skin anecdote related by Kimberly Michelle Vaughn: a group of white male improvisers collectively call out Vaughn for her Black-racialized skin, then attempt to force the scene to move towards surgery to remove that skin. Blackness is treated as a fetish object par excellence, and the white male subjects indulge in exposing it, seeking a non-gendered but sexually arousing subject-aeffect for white people. Blackness functions as the intuitive focal point at the top of the scene, as improvisational play, and provides the theme. In other words, Blackness fuels a scene that takes the surgical removal of that very Blackness as its theme. These white improvisers are experts in intuitive, playful, humorous, multidimensional anti-Black abjection. Such propertization of Black-racialized scene partners reduces their function in the scene to an enslaved Black-racialized body to be lynched, or to bodily matter whose skin should be peeled off. It creates a libidinal experience that is both sexual and subject-making, reminding the white subject-body of maternal unity and engendering a subject-aeffect. In terms of anti-Black abjection, then, the obscene and the hostile joke are one and the same. The motivating force of anti-Blackness thus largely structures white humor - especially when performed spontaneously and grounded in intuitive decisions.

\section{Blackness-as-obstacle}

One central issue in using Freud's theory of humor is his mobilization of concepts like repression and obstacles, as when he argues that the tendentious joke will "get around restrictions and open up sources of pleasure that have become inaccessible” (98). Anti-Black modernity, however, is structured by the vul- 
nerability of and gratuitous violence against anybody racialized as Black, as performed through anti-Black abjection. It is always accessible, so joking would seem unnecessary. I have a two-part response. First, speaking with both Freud and Damasio, we can assert that specific sources of pleasure (somatic configurations) do not serve only one purpose or become activated in only one way. A comparable or even identical release of or relief from tension, of Abfuhr or Entbindung, can be caused by anti-Black abjection or by the mechanics of a joke. In this sense, Blackness aeffectively becomes the joke even though the joke may not overtly draw on Blackness-as-content. If it does, its tendentious impetus is all the stronger. This is not a simplified conceptual shorthand; understanding humorous abjection as jouissance qua emotional release helps us think this through without relying on the notion of obstacles. If there is an emotional release that provides jouissance qua culturally specific anti-Black abjection, then, second, it can be found in Blackness-as-obstacle, the sexual destruction of which provides a very specific relief indeed: that of an oxymoronic "Black Humanity." This would mean that the maintenance of white subjectivity is in itself libidinally costly; white people need to invest in anti-Blackness for their own existentially subjective pleasure. When we experience the threat of losing that investment, we face an obstacle between ourselves and the reward for our investment. Considered from this angle, Blackness is the ultimate obstacle. The culturally specific sociogeny of the modern West relies on the Blackness that simultaneously threatens it, because the recognition of "Black Humanity" would dissolve the descriptive statement of what it means to be Human. As white subjects we relieve ourselves of the tension caused by this oxymoron via anti-Black abjection. This abjective praxis ensures that only white people can be Human, even if the concept's stability requires the ongoing dehumanization and continual destruction of Blackness.

Improv, as an exclusively Human activity, is foreclosed to those racialized as Black who are read as "talking bodies" at best, as Charles Mills phrases it: "Whites may get to be 'talking heads,' but even when Black heads are talking, one is always uncomfortably aware of the bodies to which they are attached" (Contract 51). When Black-racialized bodies do what they do not have the discursive capacity to do, even when they simply move in a sphere in which moving is what Humans do, they represent an obstacle. Blackness is thus in the way of real (undisturbedly abjective white) fun, and a central constituent of the humorous situation. It is transitional for the white subject who delves into abjective transitionality in humorous play. Winnicott's description of the subject-in-transition speaking to its object is again relevant: "'You have value for me because of your survival of my destruction of you.' 'While I am loving you I am all the time destroying you in (unconscious) fantasy” (121). Watkins writes plainly 
that "[s]laves as comic figures were [...] both the vehicle for and butt of the humor” $(62-63)$.

\section{Hiding Wynter's referent-we in Freud's "third person"}

According to Freud, "a tendentious joke requires three persons: apart from the one who is telling the joke, it needs a second person who is taken as the object of the hostile or sexual aggression, and a third in whom the joke's intention of producing pleasure is fulfilled" (Joke 95). A joke only exists in performative actuality, which it shares with the theatrical situation. Both rely on a configurative setup in which performers do something while being watched by an audience. Only in this setting can both fulfil their communicational and performative functions, can they make sense. This tripartite configuration also resonates with Rose's elaboration on property claimantship; after the owner's initial "moment of chutzpah: the act of establishing individual property for one's self simply by taking something out of the great commons of unowned resources," they must give "notice to the world through a clear act" (Rose 9, 13). The theatrical situation is defined by the attentive presence of an audience. In view of joking, Freud notes: "the pleasure produced by the joke turns out to be more evident in the third person than in its author" (Joke 140). Parallel to the speech act of a property claim, which is successful only when a group (or audience) consents to the claim, in humor the laughers ultimately realize the joke and mark its success or failure. The performance is only completed with the so-called third person's libidinal reaction - regardless of how or whether that reaction is expressed. (I would suggest that it only needs to be imagined by the joker, making the third person a virtual entity.) This is existential for the theatrical situation of joking. Without an (imagined) audience, an (imagined) shared communality, a joke not only achieves nothing: it does not exist.

In distinction from the comic, Freud notes the crucial (potentially imaginary) sociality of the tendentious joke:

If the joke puts itself at the service of hostile tendencies or intentions to strip [expose] someone, it can be described as a psychical process requiring three persons [...] the psychical process of the joke is consummated between the first person, the 'I,' and the third, the person from the outside. (139)

This reads at least as an analogy if not an identical procedure to anti-Black sociogeny. If we read theatrical joke-work not as technique but as affective meaning or knowledge-making that turns mythoi into flesh, it becomes existentially 
dependent in this very sociality. The function of the joke, then, can only be realized on the grounds of an (imagined or real) community. The performative effect of a joke relies on the existence (or imagination) of a group in which this culturally specific libidinal tension-relief set up can operate intelligibly. The (imagined) group must share the same libidinal ground:

[The third person] must definitely be compatible psychically with the first person to the extent of sharing the same internal inhibitions that the joke-work overcame in the first. [...] Every joke demands its own audience, and laughing at the same jokes is evidence of farreaching psychological compatibility. (145)

This is how theatrical, tendentious jokes participate in the hardwiring of the Western subject's body-brain. Freud understands humorous communication as the process of re-assertion qua audience feedback. Working from the observation that one would not laugh at one's own joke, he speculates on why subjects feel the urge to tell the joke to a third person in the first place:

We can only surmise [...] that the very reason we are compelled to pass on our joke to someone else is because we are unable to laugh at it ourselves. From our insights into the conditions for gaining pleasure and for release in the third person, we may infer that in the first the conditions for discharge are lacking and those for gaining pleasure are perhaps only incompletely fulfilled. If so, it is not implausible that we supplement our own pleasure by achieving the laughter that is not possible for ourselves by the roundabout way of the impression on the third person who has been made to laugh. (149)

Telling a joke thus provides "objective reassurance that the joke-work has been successful” and realizes the joker's own libidinal energy through feedback. The subject-aeffect caused by joking always relies on a referent-we to which it can be addressed. Freud's third person, the (imagined) listener/spectator, "bribed by the effortless satisfaction of his own libido," does not need make any effort whatsoever (Joke 95). The tendentiously propertizing speech act of the first person is directed at the third (at the cost of the second, propertized one) to corrupt them with the currency of psychical expenditure saved without effort. Given a shared libidinal ground, the third person will automatically ally themselves with the first person against the second person, who is performatively (re-)created as a communally shared obstacle, becoming the abjected non-reference for the communally celebrated and indulged subject-aeffect. On the ground of the second person, the community is, in fact, (re-)created.

This is also the sociogenic function of humor on the improv stage. The individual white subject makes a joke or performs an act of anti-Black abjection for humorous pleasure, thus bribing the audience - should there be a need for such 
a bribe - to join in the fun because the effort of performance has already been made for them. This can be activated on any level, whether through content - as in the use of the n-word or defining the scene partner as a Slave - or through subliminal effects like excluding Black-racialized improvisers from protagonist roles in collectively improvised plays (treatment like a prop), or in micro-aggressive, non-linguistic expressions of white subject-bodies perceptible to both audience and Black-racialized scene partners. These dimensions are not necessarily voluntary but are often the result of a libidinal structure that white subjects cannot easily and intentionally will away, especially not in the heated situation of live public improvisation. This is especially true in improv because improvisers perform as themselves, from their own knowledges. They speak to and laugh with their audience, intuitively tailoring their language and content to that audience, as in any other form of communication. To some degree, the improviser (unconsciously) knows or assumes a certain way of being in the world on the part of their audience, and then plays to that shared knowledge - intuitively and therefore abjectively when it comes to anti-Blackness.

Given the powerful biochemical processes of laughter (in the release of endorphins), humor is not only analogical to but actively complicit in the sociogenic procedures by which nongenetic codes (mythoi) are "neurochemically implemented," as Wynter writes ("Catastrophe” 27). The central positions of the first and the third person, as well as their interplay, can be logically related to Wynter's elaborations on the imaginary referent-we of those speaking and spoken to with the aim of kin-recognition:

This dynamic emerges, for example, in the "imagined communities" of our respective ethno-class nation-states: the genre-specific subjects of each such nation-state are enabled to subjectively experience themselves/ourselves in fictively eusocialized terms [...] as interaltruistic kin-recognizing member subjects of the same referent-we and its imagined community. As such, kin-recognizing member subjects lawlikely and performatively enact themselves/ourselves as "good men and women" of their/our kind according to nongenetically determined, origin mythically chartered symbolically encoded and semantically enacted set of symbolic life/death instructions. ("Catastrophe” 27)

Leaving aside Wynter's focus on nation, the idea of an imagined community can be linked to the actual theatrical community of improv. Improvisers are speaking - though through their fictionalized words and actions - directly to the audience. Only if there is intelligibility among them will they recognize each other as kin by laughing at the same thing. The white improviser can be a "good man or woman" of their kind by making the effort of anti-Black abjection for them, providing them with effortless jouissance on the shared ground of the modern, racialized, and specifically anti-Black life/death dichotomy. The improvised abjec- 
tion strengthens the (collectively imagined) referent-we, keeping it symbolically alive by the continual abjection of Blackness and those racialized as Black, who are discursively designed as already socially and symbolically dead. Given its material, affective, biochemical dimensions, laughter can play a powerful role in the neurochemical implementation of the social codes in biological bodies, in sociogeny. Humor and laughter program us for further humor and laughter, creating an affective and behavior-motivating autobahn that gets us there fast - "there" being the jouissance of overcoming an obstacle in order to relieve tension. This tension can be set up, as in a crafted joke with a punch line, or it can work as pure abjective tendentiousness. Staged moments of anti-Black abjection realized through the third person's laughter is thus pure sociogeny. Even if an improvising subject does not know if something was funny, the audience (even if only imagined) will let us know it was. The improvisers present themselves as good ones of their kind and the loudest, the most compulsive audience reactions reassure them that they are. We can be good ones of our kind only if we communicate as clearly as we can the already existent libidinal ground of the very culture or community to which we imagine we belong.

As suggested above, by way of conceptual analogy and performative likeness, the theatrical performance of the joke can be read through the communicational mechanisms of property claimantship. Rose makes the point that "in defining the acts of possession that make up a claim to property, the law not only rewards the author of the 'text'; it also puts an imprimatur on a particular symbolic system and on the audience that uses this system" (85). Like a property claim, the abjective, tendentious joke functions as a text performed in a social context. Blackness, whether in the form of an actual Black-racialized improviser on the stage or in fictive content that involves Blackness, serves white subjects by powering the anti-Black discursive configuration in which these speech acts can be uttered, and thus the culturally specific modern sociability to which they give rise. The linkage between white sociality as anti-Black abjection qua propertization and laughter can be made even more concrete in considering another key text in humor theory: Henri Bergson's On Laughter. In the following section, I consider the theoretical, historical groundwork of Human humor, demonstrating how the notion of humorously dehumanized Blackness has been mobilized within the Humanist theorization of humor - and the assumptions and observations on which these theorizations have been based. 


\title{
6.3 Laughable Blackness
}

\section{Psychosocial harmonization}

It may seem strange to consider Bergson's largely unfashionable superiority theory of humor, which finds probably its sole contemporary proponent in Roger Scruton. ${ }^{3}$ Concepts of superiority do not go down well in the age of mainstream multiculturalism, relativist ideology, and fetishized difference. It is not particularly fashionable (at least not in the realm of left liberalism) to take seriously concepts of superiority in popular culture or aesthetic analysis. Derogatory laughter is not something to which contemporary theorists readily subscribe, nor are they happy to accept symbolic hierarchization among humans, even though it axiomatically underlies most of the concepts applied to discuss humor. I revisit Bergson here for two reasons. First, he is one of the most influential humor theorists and one of the earliest to devote a long piece of writing to the subject, rather than using humor to illustrate other ideas (as did Plato, Hobbes, or the Christian thinkers). His essay Le Rire (Laughter) was originally published in 1900, five years before Freud's writings on jokes. ${ }^{4}$ Bergson is thus one of the founding figures of contemporary humor studies and is still continually referenced in the scholarship. Second, his essay on humor stands within his influential vitalism at large, thus drawing a connection between these two investigative frames. For Bergson, laughter is necessarily collective:

\begin{abstract}
You would hardly appreciate the comic if you felt yourself isolated from others. Laughter appears to stand in need of an echo, Listen to it carefully: it is not an articulate, clear, well-defined sound; it is something which would fain be prolonged by reverberating from one to another [...] Our laughter is always the laughter of a group. [...] However spontaneous it seems, laughter always implies a kind of secret freemasonry, or even complicity, with other laughers, real or imaginary. (Laughter 11)
\end{abstract}

From this, we can extrapolate three elements: a) Laughter is an endeavor of agency-endowed cognizers, i.e., human agents, engaging in b) a communicative process, which creates c) a community of laughing agents collectively reacting to an object perceived as humorous. This is completely congruent with the performance situation as well as with the communicative dimension of the Freudian humorous setup involving the third person, the communicational function of

3 The highly conservative and often controversial late philosopher develops the notion of "attentive demolition" in his humor theory, which resonates with Bergson and Freud (Scruton 169). 4 Freud praises Le Rire as "attractive and lively" (Joke 214). 
the prop according to Sofer, ${ }^{5}$ the communicational ground for (anti-Black) property claims, and Wynter's concept of a (potentially imagined) referent-we.

Bergson's explicit inclusion of a potentially imaginary collectivity is worth noting in that it allows humor to take place purely in the mind of an individual. An actual group of people need not be present; it suffices that the individual understands themselves as a member of a particular cultural group, assuming that others share the same code and libidinal structure. Laughter is thus an effect of the continual, societal, discursive, individually and culturally solipsistic auto-reinstitution of a community communicating with itself. Accordingly, Bergson's primary interest lies in the actual situation of humorous performance of sociality:

To understand laughter, we must put it back into its natural environment, which is society, and above all, we must determine the utility of its function, which is a social one [...] Laughter must always answer to certain requirements of life in common. It must have a social signification. (Laughter 12)

Like the Freudian joke, Bergsonian laughter in a theatrical setup presents a situation that is both aesthetic and real, in which fictions and fantasies work with and against the actual and real that can be seen on stage. Because laughter in the theatrical situation is such a condensed and public display of what is (believed to be) collectively understood as funny, it is a meaningful site to learn about the significatory power and exertion of anti-Black force. Bergson writes further:

Laughter [...] does not belong to the province of esthetics alone, since unconsciously (and even immorally in many particular instances) it pursues the utilitarian aim of general improvement. And yet there is something aesthetic about it, since the comic comes into being just when society and the individual, freed from the worry of self-preservation, begin to regard themselves as works of art. (Laughter 17)

If we think about the aesthetic and material dimensions of play, improvisation, and theater, they emerge as primary sites for humor. The reverse is also true; wherever a situation turns humorous, we see Humans at play, performing in a

5 One of the central functions of the prop, as Sofer argues, is that it establishes a temporal contract. The prop embodies "a volatile 'temporal contract' between actor and spectator for the duration of performance" (ix). This means that what a specific entity signifies on a stage is decided between the improviser who offers up that signification and the audience that accepts or rejects it, or a standardized agreement that can safely be assumed to be shared right away. It is thus a central moment in actor-audience communication, providing its medium and matter. 
theatrical situation of some sort whatever the context or analytic frame. Whether with Bergson's sociality, Freud's third person, or Wynter's culturally specific referent-we, humor and laughter are always located in the sphere of theatricality, including its sociopolitical bearings and libidinal structures.

\section{Racialized rigidity}

Bergson reads a corrective function in laughter, which is - sociogenically - supposed to optimize both the individual and the collective:

In a word, if a circle be drawn round those actions and dispositions - implied in the individual or social life - to which their natural consequences bring their own penalties, there remains outside this sphere of emotions and struggle - and within a neutral zone in which man simply exposes himself to man's curiosity - a certain rigidity of the body, mind and character, that society would still like to get rid of in order to obtain from its members the greatest possible degree of elasticity and sociability. This rigidity is comic, laughter is corrective. (Laughter 17)

It should come as no surprise that this rigidity is racialized as Blackness. At the core of his theory of laughter lies the same Manichean binary that structures his vitalist philosophy writ large: the dichotomous descriptive statement that posits white, rational, spiritual, and cognitional symbolic life vs. Black, irrational, symbolic death. In his view, laughter is a cultural mode that serves a society's ultimate (natural, teleological) cause by reasserting its ideals in order to ensure its expansion and growth. As a gesture of social sanctioning, laughter helps to correct any aberration from social ideals, so he argues. Bergson describes the ideal of the individual living in an organic society as elasticity. He suggests, in Darwinian rhetoric, that such elasticity represents an individual subject's adaptability to social norms. He defines deviations from the ideal of elasticity as "elements of inferiority," which need to be removed in order to live within that society:

What life and society require of each of us is a constantly alert attention that discerns the outlines of the present situation, together with a certain elasticity of the mind and body to enable us to adapt ourselves in consequence. Tension and elasticity are two forces, mutually complementary, which bring life into play. If these two forces are lacking in the body to any considerable extent, we have sickness and infirmity and accidents of every kind. If they are lacking in mind, we find every degree of mental deficiency, every variety of insanity. Finally, if they are lacking in character, we have cases of the gravest inadaptability to social life, which are the sources of misery and at times the causes of crime. Once these elements of inferiority are removed - and they tend to eliminate themselves in what has been called 
the struggle for life - the person can live, and that in common with other persons. (Laughter $16-17)^{6}$

Social, symbolic life is ensured by the individual's ability to adapt quickly to social demands. The ultimate Other to this constantly adaptive, elastic Human mind is the individual whose body, mind, or character is too static to "conduct in accordance with the reality which is present" (Laughter 13). Such absentmindedness (a state of mechanical lifelessness) in the Humanoid objects of humor is central in Bergson's theory: Human acts are perceived as comical if they are somehow automatic and mechanical, demonstrating a lack of self-awareness. Humorous situations include physical automatisms like tripping over a stone, and psychic automatisms such as "mathematical punctuality." In either case, the subject is not in control, not in possession of itself (like Adorno's jazz-subject), and acts like an anthropomorphic automaton, with no mind of its own and no self-awareness.

Even though this notion of a Human subject must be read as always already raced, let us follow Bergson's argument to the end. In his elaboration, the nonplus-ultra of mindless rigidity, the absolutized Other of the flexible and adaptive Human spirit - a transumption of the Divine Spirit - is the body that the modern matrix of Human existence signifies as Black: a transumption of the Fallen Flesh. Remarking on the work of the caricaturist, who "divines the deep-seated recalcitrance of matter," Bergson argues that this "art, which has the touch of the diabolical, raises up the demon who had been overthrown by the angel." The materiality of a person's physiognomy is as comical in Bergsonian theory as are all other bodily actions that draw attention to themselves or to the body that performs them. Bergson writes that "[the] attitudes, gestures and movements of the human body are laughable in exact proportion as that body reminds us of a mere machine" (Laughter 20-21). Whenever physicality (the materiality of the body) takes over, whenever the mind is absent or out of control, if "some rigidity or other [is] applied to the mobility of life," the result, according to Bergson, is funny. Rigidity foregrounds the materiality that surrounds the human spirit. His example is fashion, which foregrounds its materiality when it is out of date:

6 Bergson's elaboration sounds like a description of an ideal improviser and his rhetoric "bringing life into play" - emphasizes this echo. Elasticity as an abstract concept is one quality of a good improviser, and flexibility of the mind and elegant use of the body are central to improv stagecraft. As a result of arguments like this, vitalist ideas, however esoterically or scientifically fashioned, always appeal to improvisers. 


\begin{abstract}
Suppose [...] some eccentric individual dresses himself in the fashion of former times: our attention is immediately drawn to the clothes themselves, we absolutely distinguish them from the individual, we say that the latter is disguising himself, - as though every article of clothing were not a disguise! - and the laughable aspect of fashion comes out of the shadow into the light. (Laughter 25)
\end{abstract}

Through this example, Bergson introduces his influential idea of humor as emerging from "something mechanical encrusted upon the living," from moments in which "the living body [becomes] rigid, like a machine." He states, "it seemed to us that the living body ought to be the perfection of suppleness [...] the very flame of life, kindled within us by a higher principle and perceived through the body, as if through a glass" (Laughter 29). Perceiving this "gracefulness [...] in the living body" means to "disregard in it the elements of weight, of resistance, and, in a word, of matter" and thinking "only of its "vitality which we regard as derived from the very principle of intellectual and moral life." Yet if our attention is drawn to the material side of the principle with which it is animated, the body is no more in our eyes than a heavy and cumbersome vesture, a kind of irksome ballast which holds down to earth a soul eager to rise aloft [...] Any incident is comic that calls our attention to the physical in a person when it is the moral side that is concerned. (Laughter 29-30)

For Bergson, then, humor by its defining function abjects physicality as static, inflexible matter that restricts the Western subject's Human potential: "The comic will come into being, it appears, whenever a group of men [sic] concentrate their attention on one of their number, imposing silence on their emotions and calling into play nothing but their intelligence" (Laughter 12). In his devalorization of physicality (embodiment), Bergson locates rationality, creative intelligence, mental flexibility, grace, and the capacity to participate in sociality solely in the sphere of the mind. The mind is everything; the body is nothing. He thus works within the Cartesian mind-matter distinction and argues along the lines of the "fundamental Platonic postulate (that of an eternal, 'divinized' cosmos as contrasted with the Earth, which was not only subject to change and corruption but was fixed and unmoving at the center)," later transumed in the theocentric terms of Judeo-Christian Europe (Wynter, "Unsettling" 271-72). Compared to the eternal soul, the spirit, gracefulness, and intellectual levity, the body is weighty ballast that keeps the former from fully lifting itself up to where it rightfully belongs.

At a time when the natural sciences were advancing, Bergson's vitalism reinstalled both the theocentric and the ratiocentric matrices of thought while ensuring that Blackness-as-demonic physicality kept signifying deviance and degradation. Similarly, under the general heading of "disguise," his fashion 
metaphor is transumed into a racially abjective argumentational gesture that serves to exemplify the larger concept of the comically rigid:

\begin{abstract}
Why do we laugh at a head of hair which has changed from dark to blond? What is there comic about a rubicund nose? And why does one laugh at a [n-word]? The question would appear to be an embarrassing one, for it has been asked by successive psychologists such as Hecker, Kraepelin and Lipps, and all have given different replies. And yet I rather fancy the correct answer was suggested to me one day in the street by an ordinary canny, who applied the expression "unwashed" to the negro fare he was driving. Unwashed! Does not this mean that a black face, in our imagination, is one daubed over with ink or soot? If so, then a red nose can only be one which has received a coating of vermilion. And so we see that the notion of disguise has passed on something of its comic quality to instances in which there is actually no disguise, though there might be. (Laughter 25-26)
\end{abstract}

The analogical and metaphorical use of Black-racialized skin-as-costume aligned with a painted nose or dyed hair might appear an accident, or a negligible issue caused by the language of the time. However, it is a troubling symptom of the way in which Bergson reformulates and reintroduces a racialized hierarchy among Humans. A small rhetorical crack is in fact the punctum that provides invaluable insight into the inner workings of his concept of humor. This is not an accident but a trope that integrates smoothly into his whole argument. Blackness for Bergson serves the same affective function in the argumentational dramaturgy of reasoning that it fulfils in Adorno's jazz critique. It is not just there. Here the whiteness of Bergson's putatively universal (but really culturally specific) us-collective, his referent-we, becomes clear. A look at the applied deixis shows that his generalized account of laughter is not only addressed at his white European audience, but is in itself a performative act of reinstating their white universalized Human subjectivity. He presumes shared knowledge, experience, and judgment between himself and his readers, a harmonizing collective of laughers (which he terms a "closed circle") laughing at Black-racialized skin. The positionality of the laughing Human is established as the white European default. There is more to say about the wider context of this cab-driver's encounter with Blackness, which I will consider in more detail below.

\title{
“They get laughs for that:” making Blackness matter
}

Black skin is presented as skin-like. It is read as humanoid. And yet it is mobilized as a specific kind of skin that foregrounds its physicality, its materiality, its bodily rigidity, its skin-ness. Like a painted nose or an outlandishly outdated dress, Black skin-as-metaphor serves to illustrate static matter, which restricts 
the Human within it. It thus signals a lack-of-Humanity if we take Bergson's discussion of the caricature seriously. In this context, the consequence of Bergson's logic is that Black-racialized skin becomes an outer representation of an inner deficiency. It does not symbolize Human life because, for Bergson, it has a thingly quality, which creates humor when set in contrasting relation to Humanity. For his argument to be logical, Black-racialized skin must then stand in opposition to the living Human being. Black skin-as-metaphor is analogized with the wearer of an eccentric piece of clothing who is "embarrassed by his body, looking round for some convenient cloak-room in which to deposit it" (30). The ease with which Bergson can put forward this list of analogies makes his claim that we laugh when "the body takes precedence of the soul" because "a person gives us the impression of being a thing” (33) a representative example of this project's thesis. Bergson's idea of humor must be read along with the way in which Black improvisers are propertized when the actuality of their bodies is foregrounded. Freud too suggests that tendentious jokes draw attention to a given physical aspect of a person. This corresponds to the psychosocial calling out of physical features on the improv stage, which equates with collectively abjective dehumanization. Consider this anecdote by Kimberly Michelle Vaughn:

I remember I did a scene one time with a girl. It was in a LaRonde and we're on the bed. We were talking about eating marshmallows, the most stupid thing. And then she was like, "Yeah, but you're black." And I was like, "What?” I stopped everything I was doing in the scene and focused on that. "What does that mean 'I'm black?" I remember being mad at myself for stopping the scene in that way, but I really wanted her to feel stupid. I wanted her to go home and cry for being a dumbass. For calling me out for that. Mostly improvisers get laughs for calling me out for not being "black enough.” They get laughs for that. (personal conversation)

Vaughn is called out on her Blackness and is thereby propertized, abjected, immobilized, stripped of the ability to signify anything other than that Blackness. Without her consent, her body is dehumanized, matter-ized, and abjectively made to take "precedence of the soul" - for a laugh.

Even though Blackness as a property of laughter and an obstacle to Humanity may have gained popular momentum for and within the specific historical background of the US, many examples of Blackness are mobilized to generate a comic effect beyond this temporal and geographical context. Consider one from a 1985 German comedy movie: Otto - Der Film, still one of the most successful German movies. In the film, comedian Otto Waalkes has a scene in which the protagonist, played by himself, meets a Black-racialized US soldier on the street carrying a boom box on his shoulder. Otto pays him 50 D-Mark to act as a Slave so that Otto can sell him to an elderly lady two days before the "slave trade will 
no longer be allowed." After the transaction, Otto, in a different costume, claims that the lady is not the rightful owner of this Slave because she cannot present the correct documents to "own a Slave." While the elderly lady's ignorance and German bureaucracy are also themes here, it would be nonsensical (that is, libidinally incomprehensible) if anti-Black abjection were not mobilized. Even if Freud states that we do not always know what makes us laugh, in this case the tendentious quality of anti-Black abjection makes the joke work. The scene in which Otto meets the Black figure, portrayed by Günter Kaufmann, is an effective example of how Blackness does not need the obvious reference to enslavement to be funny-for. Slavery is not the joke here but Blackness-as-such. The GI does not immediately reply to Otto's approach, and Otto thinks he doesn't understand, explaining in a mock African accent: "Black head, black belly, black feet." Looking at the still confused eyes of the nameless character, Otto takes off one of his socks and presents his own coal-colored foot, which is then met with great appreciation and understanding on the part of the soldier. Even though minstrelsy would not be on the mind of the mainstream German audience, the dehumanizing notion of Black skin as a dead crust costume is transatlantically intelligible as "humorous" and the idea of Blackness is demonstrably funny as such. When asked by his new owner how, "being a slave," he would like his coffee, "Herr Bimbo" provides the punchline: "black."7 This scene is only libidinally intelligible because Blackness cannot represent Human life, just as Vaughn's experience is only possible because her Blackness bears an inherent comic potential for her scene partner and audience. If Blackness could represent Human life, Bergson's argument would not operate. The winner of the 1927 Nobel Prize not only works within the logic of white social life and Black social death; he also performs and reenacts these dialectics in his widely-received essay on humor. His theorizing is anti-Black abjection in action, and thus offers insight into how subjects of the anti-Black modern West are funny.

\section{Fantasies}

Freud summarizes Bergsonian humor theory as follows: "The cause of laughter in these cases would be the divergence of the living from the lifeless" (Joke 201).

7 The German term "bimbo" is a false cognate in that it is not the same as the derogatory English slang term for women deemed unintelligent. The German term activates the libidinal signification of both the n-word or other derogatory terms for Black-racialized people, such as "darky." It connotes "being enslaved" as well as "natural servility," as in "I am not your Bimbo." It is used interchangeably with the n-word. 
His reception of Bergson provides an effective summary of the affective, libidinal ground on which humor (theory and practice) is variously performed, and how it creates a fundamentally anti-Black, dehumanizing form of comedy culturally specific to Western modernity. Within the framework of this project, Bergson's analysis of laughter locates the pleasure of humor in the experience of the white subject as a subject in (an) order. It is the experience of performing in a theater of self-perception, self-assertion, and self-aeffection based on the idea of belonging to a community of laughers who share a cultural value system and grammar. Such sociality creates the aeffect of the subject experiencing itself as a coherent unity within this order - an order whose coherence is paradigmatically defined as and organized around acts of anti-Black abjection. Laughing with Bergson always and necessarily involves acts of anti-Black abjection. Bergsonian humor theory provides ample examples of how white Humanities are parasitic on the semantics of Black social death, as does its ongoing reception and transumption.

Bergson does grant that his approach brings about "a fresh crop of difficulties." He argues that while for "reason," statements like "A red nose is a painted nose" or "a [n-word] is a white man in disguise" are absurd, "they are gospel truths to pure imagination." I transpose what Bergson describes as fantasy into a collective-affective linguistic signification, framing it as a sphere of internalized, embodied, and culturally specific knowledge. He writes: "So there is a logic of the imagination which is not the logic of reason, one which at times is even opposed to the latter, - with which, however, philosophy must reckon." Significantly, Bergson understands this imagination as a collective rather than individual fantasy: "It is something like the logic of dreams, though of dreams that have not been left to the whim of individual fancy, being the dreams dreamt by the whole of society." As an ideological structure of feeling, a white libidinal economy could hardly be better exemplified. This Bergsonian imagination is not a source for true creativity but speaks to a socially coded anti-Black matrix that works through humorous affects. It is individual and social, biochemical affect as well as code, bios as well as mythoi. Laughter and humor are sociogeny. Addressing their culturally specific whiteness cannot be theorized without recognizing their anti-Blackness, as exemplified by Bergson's theorization. Much like Adorno, Bergson was both partaking in and onto something. Still, his theory is too racially restricted (and universalist) to allow him to comprehend its full cultural implications. For Bergson, the Black-racialized person simply is ontologically funny for the universalized, white supremacist referent-we of Western modernity: "A man in disguise is comic. A man we regard as disguised is also comic. So, by analogy, any disguise is seen as comic, not only that of a man, but of that society also, and even the disguise of nature" (Laughter 26). If Black-racialized 
skin could - discursively - mean anything other than a dead crust costume, Bergsonian humor theory would collapse, its logic dissolve, its seemingly unraced elements lose their hold. ${ }^{8}$

\subsection{Incongruities}

\section{Foundational Manicheanism}

Even though Le Rire is a landmark in the development of humor studies, it was not developed in a void. Here I briefly consider the category of humor theories labelled "incongruity," including early theorists of humor Francis Hutcheson and Herbert Spencer and psychologists Kraepelin and Lipps, to whom Bergson and Freud explicitly refer. This little detour shows how anti-Blackness has always been instructive for the generation of humor theory even under the abstractified terms of a general "incongruity." Hutcheson is one of the most prominent forefathers of what came to be called "incongruity theory." For him, incongruity is not yet an abstract concept, but is built on the binaries of modern self-making: "According to Hutcheson, the cause of laughter resides in contrasts such as between 'grandeur, dignity, sanctity and perfection and ideas of meanness, baseness, profanity”' (Carroll 17). Hutcheson, an early abolitionist, drew on the modern transumption of Heavenly perfection and Earthly imperfection. His incongruity is therefore not abstract but decidedly hierarchical. Even though Blackness does not feature overtly in Hutcheson's writing on humor, he is attached to the Platonic postulate and transumptive chain of descriptive statements that followed it. His work is taken up by Herbert Spencer, who writes in the same vein: "Laughter naturally results only when consciousness is unawares transferred from great things to small - only when there is what we may call a descending incongruity" (206). The points of contact between Spencer and Freud are obvious; Spencer was the first to describe humor as an "economical phenomenon" in the service of regulating "psychic energy.” Like Freud, Spencer also conceived of psychic energy in physiological terms (206). ${ }^{9}$ This strand of

8 In anthologies of humor (such as Texte zur Theorie der Komik (2005), regularly used in German universities), the section in which these underlying racial axioms are laid out is edited out. 9 "Among the several sets of channels into which surplus feeling might be discharged, was named the nervous system of the viscera. The sudden overflow of an arrested mental excitement, which, as we have seen, results from a descending incongruity, must doubtless stimulate not only the muscular system, as we see it does, but also the internal organs; the heart and stomach 
humor theory has since become generalized and abstractified, so that incongruity denotes general "mismatches" between objects and the concepts they represent, scripts (Raskin), or second-degree concepts. The list of incongruity theorists is long and includes Schopenhauer, Kant, and Raskin, and more recently Marteinson and Arthur Koestner, among others. Koestner's frame-oriented concept of bisociation, as developed in The Act of Creation, is widely discussed. He conceives of humorous collision when the humorist joins "two incompatible matrices together in paradoxical synthesis." The audience has its "expectations shattered and its reason affronted [...] instead of fusion, there is collision; and in the mental disarray which ensues, emotion, deserted by reason, is flushed out in laughter." Here Koestner specifies emotions of "the self-assertive, aggressive-defensive type," which links his thought to Freud's notion of the tendentious joke and to my reading of it as gratuitous abjection (94-95). And yet, how has this incongruity originally been grounded?

In mobilizing the trope of a white carriage driver and his Black-racialized fare, Bergson positions himself in a trajectory that includes Kraepelin and Lipps as two theorists among others, all of whom were outstripped by the carriage driver whose undifferentiated reaction to a Black-racialized customer drives his own abjective and absolutist theory. Under closer investigation, however, it can be seen that Bergson does not differ significantly from his predecessors. For Bergson, it is important that the bemused cab-driver does not differentiate between whether Black-racialized skin is natural or was put on like a disguise by a white subject. In the sphere of superiority, this misfit designates a fundamental inferiority because the white subject can read Blackness only as a dead crust on the living. In this section, I will consider those writers whom Bergson sought to distinguish himself from when he wrote that "successive psychologists such as Hecker, Kraepelin and Lipps [...] all have given different replies” to the question why one laugh[s] "at the [n-word]" (Laughter 41).

In the essay "Zur Psychology des Komischen” (1885), Emil Kraepelin considers an "intellectual contrast" (132) as the fundamental concept underlying humor, which combines three kinds of comedy: visual comedy, situation comedy, and wordplay/jokes. Of these, visual comedy is presented as the "most elemental form of intellectual contrasts." The central idea is that a simple external stimulus can partly be explained by the subject within the concepts and terms of earlier experience, while other parts of that stimulus are perceived in sharp contrast to them. Kraepelin conceives of the perceptive moment as pure and sensual. The

must come in for a share of the discharge. And thus, there seems to be a good physiological basis for the popular notion that mirth-creating excitement facilitates digestion” (Spencer 207). 
humorous, then, contrasts with "our treasure of imagination [...] without further intellectual processing" (134). The judgment is therefore intuitive in the strictest sense of the term:

So it happens that to the child's experience, everything new or unfamiliar seems very light if not outweighed by fear - e. g., the dad in a new suit, a lady in ballroom, a doll with real curly hair, a parrot, etc. The peasant laughs at the [n-word] he sees for the first time; he laughs at the art rider and the ballerina, sights that we have long since got used to. (134, my translation $)^{10}$

In this excerpt, Blackness again serves as a marker of absolute Otherness to Humanity - on the same level as a new suit on a man, a new dress on a woman, a dead object with real hair, and an animal that speaks. Blackness needs no additional element to be in humorous contradiction with Humanity, to be humanoid it signifies in itself non-Humanity in the appearance of Humanity. Kraepelin's concept of visual comedy relies on an ultimate difference within the mind of the laughing cognizer. The underlying axiom recalls Bergson: Blackness in itself is conceived of as just as funny as a rigid, Humanoid prop that cannot move on its own. Kraepelin's mobilization of the n-word assumes that the white cosmopolitan self has already gotten used to seeing Blackness, whereas the rural farmer still finds it funny at first sight. In his essay "The Racial Ruse: On Blackness and Blackface Comedy in fin-de-siècle Germany," Jonathan Wipplinger relativizes the application of the farmer-encounters-Blackness trope by pointing out that in Kraepelin's argument, the trope allegedly does not play solely on the Blackwhite-binary, but also between rural and urban space in that it locates the farmer in urbanity, where it was actually possible for him to encounter Black-racialized people:

The farmer's laughter [...] has been made possible through the growth of urban exoticism such as Völkerschauen of Hagenbeck, but also of African, African American and blackface performers in the variety theater. [...] Laughing at the "[n-word]" [...] emerges within Kraepelin's text as a rite of initiation into modern urban space, a space marked by entertainment and Blackness. (463)

10 "So kommt es, dass der kindlichen Erfahrung alles Neue, Ungewohnte sehr leicht, wenn nicht die Furcht überwiegt, komisch erscheint, z.B. der Papa in einem neuen Anzuge, eine Dame in Balltoilette, eine Puppe mit wirklichen Locken, ein Papagei usw. Der Bauer lacht über den [n-word], den er zum ersten Male sieht; er lacht über den Kunstreiter und die Ballerina, Anblicke, an die wir uns längst gewöhnt haben.” 
However, rather than disproving the racism of the trope, this observation underlines the function of Blackness for modern white negotiations of subjectivity - in this case, between rural and urban spaces. It provides another example of the fungibility of Blackness to engender white-on-white negotiations around shifting formations of sociability to which Black-racialized individuals themselves have no access as subjects. By positing themselves as cosmopolitan members of the world, as opposed to those they demean as provincial and backward, white inhabitants of the "urban jungle"11 draw symbolically on Blackness as a means to shore up their superiority, which in no way includes those racialized as Black. Notably, the notion of the "urban jungle" is still mobilized today. The Second City's diverse ensemble, originally termed "BrownCo," was renamed (transumed) within the logic of the topos:

I got my good start at Second City at the comedy studies first. And then they hired me to do "Urban Twist;" they used to call it "BrownCo." It's still not a name that we like or that people appreciate. The people who do the show only name the revue. They don't name the group. So that was out of our hands. (Boyd, personal conversation)

At the time of writing, the ensemble still carries the peculiar name it was given by white theater producers.

Kraepelin does not go into the details of his own racialized axioms of difference, but psychologist and philosopher Theodor Lipps does. Lipps was one of the most respected psychologists of his time and influenced much of Freud's writing on humor and other aspects of psychoanalysis. Lipps inspired Freud's concept of laughter as a result of psychic blockage by analyzing how "consciousness becomes static and locked onto a specific object, imbuing it with cathected energy until it can be released" (Wipplinger 464). Before Freud and Bergson, Lipps announces: "The factors of psychic life are not the contents of consciousness, but the psychic processes which are in themselves unconscious" (pos. 2166, my translation). ${ }^{12}$ Unsurprisingly, in Komik und Humor (1898), Lipps too builds on the farmer-encounters-Blackness trope. He compares Black-racialized skin to non-average physical features, like a nose that's too small or too large - the former appears to create the impression of a "lower level of intellectual life" because it looks like a child's nose, while the latter is

11 Charles Mills writes: "One might argue that in the United States the growing postwar popularity of the locution of 'urban jungle' reflects a subtextual (and not very sub-) reference to the increasing nonwhiteness of the residents or the inner cities" (Contract 48).

12 "Es gilt also der allgemeine Satz: Die Faktoren des psychischen Lebens sind nicht die Bewusstseinsinhalte, sondern die an sich unbewussten psychischen Vorgänge.” 
excrescent, inappropriate, and pointless. In either case, for our imagination, he claims that the impression of the "form" diminishes the "content," that is, "the entirety of the organism and the life that fills it" (pos. 750). By way of analogy, he brings in Blackness, combining both "type" and "skin color":

Similarly, type and skin color of the [n-word] are laughed at by the uneducated [...] Generally speaking, the [n-word] type evokes the idea of a lower level of development; the color of the skin is, to say the least, incomprehensible to the uneducated as the color of a human body. (pos. 764, my translation) ${ }^{13}$

Lipps repeatedly makes the point that such racial laughter is something only the uneducated would fall for, but nowhere does he suggest that Black skin can signify Humanity. Rather, he builds on the notion that Black skin is an obstacle for the white person to recognize full personhood in what otherwise appears to be a Human body:

The perception of those human body shapes that the [n-word] shares with us creates an active willingness to connect with the [n-word] body the same assumption of a physical and mental life that we cannot but ascribe to our own bodies. (pos. 989 , my translation) ${ }^{14}$

While he repeatedly assumes this tension between possibility and impossibility can be overcome, he nonetheless uses Blackness as the argumentational ground of a generic newness, which is by definition ultimately humorous:

[The skin of the (n-word)] is new to the child, and to the naive person in general. It has not yet become comprehensible and familiar to them as a color which, just like ours, has the right to signify humanity. And yet it does lay claim to this special dignity in the eyes of the child and the naive person. According to perception, it actually has this dignity, i.e. it has it for the perceiver at the moment he surrenders to pure perception. However, this dignity melts away as soon as the first impression is over, and with it the habit of looking at white (and white only) as human skin color takes effect. Black skin color no longer appears

13 "Unter denselben Gesichtspunkt stellt sich der Typus und die Hautfarbe des [n-Wort], über welchen der Ungebildete lacht. Der [n-Wort]typus erweckt allgemein gesagt die Vorstellung einer niedrigeren Stufe der Entwicklung; die Hautfarbe ist wenigstens dem Ungebildeten als Farbe des menschlichen Körpers unverständlich.”

14 "Die Wahrnehmung der menschlichen Körperformen, die der [n-Wort] mit uns gemein hat, erzeugt aktive Bereitschaft, mit dem [n-Wort]körper ebendenselben Gedanken eines in und hinter den Forman waltenden körperlichen und seelischen Lebens zu verbinden, wie wir ihn mit unserem Körper zu verbinden nicht umhin kommen.” 
to be entitled to this claim. It appears like an external coat of paint. Comedy has come into being. (pos 1188, my translation) ${ }^{15}$

Skin color again signifies ultimate alterity. Wipplinger agrees that "the farmer's laughter is the result of a dialectic of worth and worthlessness, of humanity and non-humanity, of 'white' and 'black" (464) and that for "the farmer, if not for Lipps, the question remains as to whether the Humanity of the Black man is valid or whether he is a phony, a blacked-up white man" (465). The Black-racialized man appears Human despite his Blackness. The moment it is revealed that the Black body does not actually house a Human mind or soul, there is the humor of relief and vice versa. The perception of a "Black Humanity" does not conform to the modern white supremacist episteme in which Blackness is bound to signify the absolute Other, providing the referential ground for the abstractified static (as Bergson would have it two years later). Indeed, the farmer's (or carriage driver's) fictional experience demonstrates precisely the crisis that humor theorists seek to solve. In so doing, they develop universalized accounts of what is funny and how humor operates. We are looking at a productive but solipsist white crisis inspired by the mere presence of Blackness. If they tackle this crisis in slightly different ways, the fundamental binary of incongruence is the same. The crisis that takes hold of the carriage driver is the same crisis in which Kraepelin, Lipps, and Bergson find themselves. The cab driver laughs. The scholars write about laughing. Both abject.

I have suggested that the influential concept of incongruity is always conceptualized and mobilized in combination with the white abjective jouissance of dehumanizing Blackness. It has, however, been continually abstractified so that the originary anti-Blackness, its affective dimension, and its relationship to superiority theories are no longer visible. In the trajectory of incongruity theory, we can observe an absolute abstraction that ends up at statements like "what is key to comic amusement is [the deviation] from some presupposed norm -

15 "[Die Hautfarbe des (n-Wort)] ist dem Kinde, und dem naiven Menschen überhaupt, neu, d.h. sie ist ihnen noch nicht als Farbe, die ebensowohl wie die unsrige das Recht hat, Menschenfarbe zu sein, verständlich und geläufig geworden. Darum erhebt sie doch auch in den Augen des Kindes und des naiven Menschen den Anspruch auf diese besondere Würde. Vielmehr sie hat diese Würde nach Aussage der Wahrnehmung tatsächlich, d.h. sie hat sie für den Wahrnehmenden in dem Augenblick, in dem er der Wahrnehmung hingegeben ist. Diese Würde zergeht dann aber, sobald der erste Eindruck vorüber ist, und damit die Gewohnheit, als menschliche Hautfarbe die weisse und nur die weisse Farbe zu betrachten, in Wirkung tritt. Jetzt erscheint die schwarze Hautfarbe nicht mehr als zu diesem Anspruch berechtigt. Sie erscheint wie ein äusserlicher Anstrich. Damit ist die Komik ins Dasein getreten.” 
that is to say, an anomaly or an incongruity relative to some framework governing the ways in which we think the world is or should be" (Carroll 17). This abstraction corresponds to other transumptions of Blackness into the invisible, paradigmatically exemplified by the German usage of the term digger. What about this abstractified incongruity, and what about humor theories that are so fundamentally based on it? Embodied cognition can help us integrate several things here. First, even abstract thoughts are fundamentally physical and biochemical. Claxton considers mathematics - probably the sphere where abstract objectivist truth is cherished most highly - "a world of abstract entities that make patterns" (159), but cognition remains fundamentally physical: "the superstructure of mathematics is indeed underpinned by the childhood foundation of counting one's fingers" (160). Even mathematical variables can only function on the physical ground of the body-brain's perception - meaning there is no "purely aesthetic incongruity" to provide the basis for a purely aesthetic understanding humor. In other words, there is no such thing as an innocuous joke.

\section{"Where is your brain from?" the ambiguity of Blackness-as-superpower}

I conclude this chapter by returning to the world of improv. For those regularly affected by it, it has always been obvious: the "fact of blackness" (Fanon) matters - in improv and everywhere else. In the above discussion of humor and its performative dimensions, I considered various ways to frame white reception of Black theatrical and/or comedic performance. I now take a last look at what Black-racialized improvisers see as a direct effect of their Blackness on the improv scene, both on stage and in its social dimensions. Ironically, for many, Blackness often presents itself as an involuntary superpower:

The first time I realized that the advantage of being the one person of color was when I was doing a show in a pretty large-sized theater, and the suggestion we got was "My Way." What instantly came to my mind was Usher's biggest album, his first big R'n'B album was called "My Way," and I love Usher, so I was like "Oh, this is a scene about Usher," and everyone else was like "What?" That is what makes improvisers of color unique; they can just think like themselves and are therefore much more entertaining and way more successful. The audience was like, "Where is your brain from?" I like to play with that a lot. It's kind of an advantage. It's liberating to find that. (Bullock, personal conversation)

Traditionally progressive concepts argued in the registers of insightful laughter, laughing at oneself, overcoming ignorance through the insight of the philosopher/comedian, and others may be read into Bullock's sense of liberation, like the notion of the outsider as a particularly apt comedian who pokes fun at the 
majority. However, I personally cannot provide such an optimistic interpretation. In this project at large, and in the previous sections on humor and Human vs. non-Human incongruity, something else is at work. Just by thinking like themselves, Black-racialized improvisers prove funny to their predominantly white audience. By applying the logic of racialized incongruity elaborated by Lipps and others, one can deduce that a culturally specific white reading of Bullock's performed Usher-association (and its interpretation as humorous) is grounded in the perceived grotesqueness of a speaking Black body that appears momentarily to have Human qualities, which - on the grounds of our modern episteme of anti-Blackness - white subjects intuitively believe to know it does not have the discursive capacity to house. To articulate this experience in Koestner's theory of bisociation: white expectations are shattered, white reason is affronted, and "instead of fusion, there is collision; and in the mental disarray which ensues, emotion, deserted by reason, is flushed out in laughter" (95). In Koestner's theory, fusion in humor is impossible, and "self-assertive, aggressive-defensive" laughter only ensues from the collision of two incompatible matrices. Bullock assumes that the question driving the audience's reaction may be "Where is your brain from?" It might also be an aggressive and only putatively empathetic "Strange. It looks like she has a brain!" A white audience finds (racialized) humor in the incongruous moment when Black-racialized performers act as their Black selves. ${ }^{16}$ And yet, we must not forget that Black improvisers may find a sense of liberation in recognizing and acknowledging the performative and discursive violence against them. Bullock appreciates the net result of this constellation as an advantage ("It's so easy to blow their minds. Because they don't know anything about me, anything I tell them blows their minds.”). Nonetheless, an unnerving ambivalence remains in the fact that, just by talking, the Black body generates humor for its white audience.

A longer rumination by Joel Boyd about being Black in this world speaks to the entire investigative field of this project by "wallowing in the contradictions" (Wilderson, "Wallowing”):

16 This might also explain the tremendous current success of Dave Chappelle for a white audience. The greater the excellence and genuine admiration of his writing, the greater the incongruity becomes. Black comedic performance may have a more powerfully abjective function for its white audiences, the higher its aesthetic and performative quality is valued. This allows liberal, progressive elites to delve into anti-Blackness as well - because we can now claim that we really cherish the comedy, while in fact we cannot differentiate the comic from the comedian and are thus bound to the primary collision of matrices. 
One of my old directors - he directed my first Urban Twist show at Second City - said to us: "I know a lot of you are new to the community and Second City and I just want to address any questions about what it's like to be a minority in this building." And we ended up going on this weird tangent, and he ended up saying that the worst thing that can happen to us is to be black and mediocre. You can't be black and mediocre because first all you stick out anyway because you look the way you do. And if you suck, that's obviously really bad. But if you're mediocre, if you're not the funniest person on stage, it's just hard to watch. I started to notice that, and it's true. It's almost like a handicap that you have to make a superpower. If you're the only black person in a scene, you're automatically driving that scene. You or your character has to have some opinion or emotion. For white people, it's easy to just be with the group because they don't have that other cover. They don't represent anyone else but themselves. But if you're black, you carry that history too, and you have to be conscious of that. You can't take that lightly. You can't be mediocre. You can't be just one of the group and be "good." It's fun that I already have something that sets me apart. It's not fair, but it's true. If you look different, you have to be better. It's a handicap that you need to turn into a superpower. (personal conversation)

Boyd shares this experience with Aaron Freeman, the first Black improviser on the Second City stage:

I will tell you one skin color thing that was a huge deal at Second City, and one of the big, huge reasons I sucked - which is that I always, always, was representing the race [...] It wasn’t just me - I was representing brown people everywhere [...] I couldn't live up to it. I couldn't carry the 40 million people on my back on stage at the Second City [...] And I was so worried about it [...] that I could never relax - I couldn't be as good as I actually am. (Freeman qtd. in Seham 28-29)

For those who believe in progress, there is little evidence of it since Freeman was hired to perform for a Second City touring company in 1976. Instead, we see 40 years of stasis within a segment of popular culture that conceives of itself as democratic, free, and progressive. For those who uphold the ideal of improv's egalitarianism, its free and fair play, this is also a game-changer. What presented itself to Boyd as a "weird tangent" speaks directly to the non-existent center of this project; these anecdotes articulate the fundamental groundswell of antiBlackness, and need no further interpretation. "Weird tangents" will always lead to punctums that help us make sense of empirical facts we cannot even begin to understand otherwise.

Boyd also states that "If you look different, you have to be better," which can be both an unfair demand that undermines any egalitarian fictions and a productive challenge. Bullock and Perkins also address this bind:

Bullock: Being an improviser of color is doing extra work. For one, you very likely will not be in a group similar to you. You're very likely to be the only person of color in your group, 
in your show. It's very likely that your audience is going to be predominantly white. You are already agreeing to do extra work.

Perkins: But I think it's that because of this extra work - and I know that certain of my peers get so mad about it - but I understand why people of color progress quicker. Because they have to do more work, but it's not even spoken about.

Bullock: It's not just an improv thing. It's like in life.

Perkins: You have to be quicker. If I am always constantly paraded with these race things, I have to be able to counteract quickly. That just makes me quicker at responding. (personal conversation)

When white improvisers cherish improv for being like life, this is also true Black improvisers in the very different ways highlighted here. The involuntary and nonsociable position of the Black-racialized improviser, structurally forced to "turn a handicap into a superpower" in order to practice improv, is located within the abjected space of discursive, symbolic incapacity (not individual incapability). Being Black is an obstacle for real white play because real play is something that Humans with full subjective capacity do:

\begin{abstract}
Bullock: As a black improviser, you will always have ups and downs because people will try to convince you that you're too black. No matter how good an improviser you are, even if you're on the very main stage at Second City, the top pinnacle of improv, people will be like “Erm - too black!” People will assume that you're too different, that you're pulling the race card too much, that you're exploiting the fact that you're black. It doesn't process to them. They're just like, “The only reason people laugh at you is that you make these jokes." Like you're having this bag of black people tricks. "Stop pulling out black people-tricks so you can improvise with the rest of us and not stand out!" There are people who feel that way.

Perkins: This is not a bag of tricks. This is my life, my personality.

Bullock: My blackness isn't a bag of tricks. It's a thing that happens. I cannot take it off, so I might as well embrace it all the time. I will never not be black on stage, you know. So why not play a black person? If I don't say I'm black, then maybe I'm not, but as far as I am concerned, I am black all the time. (personal conversation)
\end{abstract}

I will say one last thing about Blackness: I remain awestruck by the fact that we are living in a world where the people who inhabit the sphere of discursive incapacity come out of it so much stronger than those with all powers of subjective capacity. Throughout this project, I have offered many angles on what first presented itself as a structural absence, but at this point in the analysis, all that remains for me to do is take a deep bow at those who live Blackness despite everything - and recognize their ultimate authority on the subject. 